\title{
CHAPTER 7 THE MYSID-FEEDING GUILD OF DEMERSAL FISHES IN THE BRACKISH ZONE OF THE WESTERSCHELDE ESTUARY
}

\author{
K. Hostens - J. Mees \\ University of Gent, Department of Biology, Marine Biology Section, Ledeganckstraat 35, B-9000 Gent, Belgium
}

63962

Key words: stomach content, consumption, Mysidacea, flatfish, gobies, gadoids, clupeoids

Published in Journal of Fish Biology 1999, 55: 704-719

\begin{abstract}
The demersal fish fauna of the mesohaline zone of the Westerschelde estuary (south-west Netherlands) was sampled intensively in the period 1990-1992. Almost 500 beam trawl samples were taken in both subtidal (330 samples) and intertidal (144 samples) habitats. These yielded 44 fish species, mostly as juveniles. The area was found to function as a nursery for several demersal fish species. and harboured large populations of hyperbenthic mysids. Three gobies, three flatfish, one clupeoid and one gadoid dominated the fish fauna, while three mysid species were important components of the holohyperbenthos. From c. 1500 stomach contents of 25 fish species, 44 prey species were identified, the most abundant of which were also common in the hyperbenthal. The demersal fish community consisted of a group that foraged subtidally on fast-moving epi-and hyperbenthic prey (for example gadoids, gobies and clupeoids) and a group that foraged on slow-moving or sessile endobenthic organisms, mainly in intertidal areas (for example most flatfish species). Mysidacea occurred in $>50 \%$ stomachs analysed and were taken as prey by 19 of the 25 fish species. Mysids were most important in the diets of Pomatoschistus minutus, P. lozanoi, Trisopterus luscus and Merlangius merlangus, and were present in appreciable numbers in Pleuronectes flesus, Trigla lucerna, Clupea harengus and Pleuronectes platessa. These species fed mainly on the brackish water endemic Neomysis integer. Mesopodopsis slabberi (present in $35 \%$ of the gobiid stomachs) and Gastrosaccus spinifer (present in $25 \%$ of the gadoid stomachs) were of secondary importance. P. minutus and T. luscus showed a diet shift from calanoids (Eurytemora affinis and Temora longicornis) to mysids at $L_{S}$ of $30 \mathrm{~mm}$ and $50 \mathrm{~mm}$, respectively. Only $1 \%$ of the standing stocks of the N. integer and $M$. slabberi populations (as measured at the moment of sampling) was removed per day by the local demersal fish community, so top-down control of mysid populations in estuaries seems unlikely.
\end{abstract}

\subsection{Introduction}

Lumping of taxonomically often very different species into trophic guilds (groups of species or size classes of species that share similar preys) has become an important tool in reducing the complexity of ecosystems for the description of local food webs (Elliott \& Dewailly 1995). Recent studies suggest that, although the species composition of the fish fauna can differ significantly between estuaries, simi- lar feeding guilds can be distinguished over wide geographical ranges (Costa \& Elliott 1991).

Most estuarine fish species are known to be opportunistic feeders, although their diet is more or less restricted to part of the total available prey spectrum as dictated by their capability to capture and ingest specific prey species. Therefore, most dietary shifts (ontogenetic, seasonal, or shifts towards the most profitable prey) are related to e.g the trophic adaptability of the fish species, food partitioning and/or seasonality in the availability of preys (Gerking 1994). 


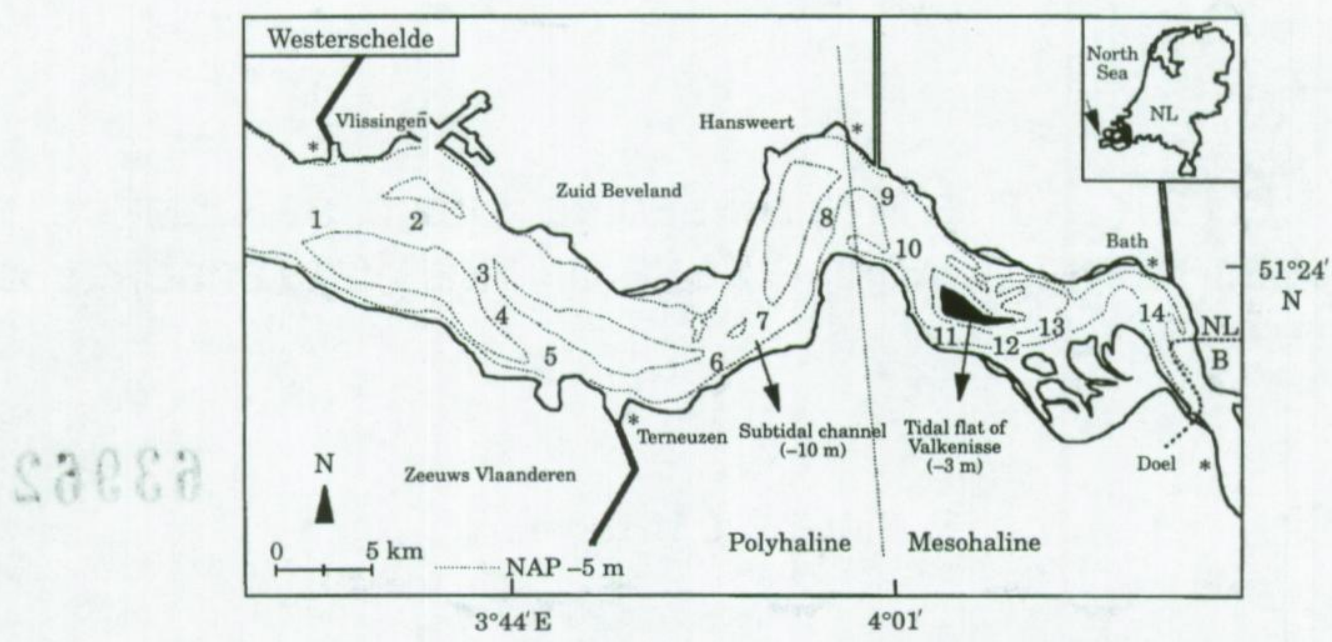

Fig. 7.1 Map of the study area with location of the 14 stations in the subtidal channel and of the intertidal flat of Valkenisse

In the mesohaline subtidal zone of the Westerschelde estuary (average salinity for the study period: $19.1 \pm 3.6 \mathrm{psu}$ ) the hyperbenthos reaches maximal densities (Mees et al. 1993b, Mees et al. 1995), while almost no macro-endobenthic organisms occur (cf. burial and clogging of the feeding apparatus in highly turbid areas). A hyperbenthosfeeding guild has been distinguished recently in several studies of demersal fish assemblages (e.g Moreira et al. 1992). The hyperbenthos mainly consists of peracarid crustaceans and larvae of a variety of taxa, and several endobenthic species perform regular excursions into the hyperbenthic layer (Mees \& Jones 1997). Mysidacea, the most typical hyperbenthic taxon, occur abundantly in estuaries where they are an important component in the diet of several fish species (Mauchline 1980). The size of estuarine mysids $(\mathrm{mm})$ is intermediate between that of mesozooplanktonic $(\mu \mathrm{m})$ and endo- or epibenthic (cm) prey items, and often they replace copepods progressively in the diet of post-larval and juvenile fish (Sorbe 1981). The presence of an estuarine mysid-feeding guild of demersal fishes in the Westerschelde was investigated by means of stomach analyses of representative length classes of all fish species that utilise both intertidal and subtidal habitats in different seasons. Correlations between the stomach content data and the availability of different mysid species in different seasons and habitats are discussed.

\subsection{Materials and methods}

The Westerschelde estuary is the lower part of the river Schelde and is located in the so-called Delta area in the south of the Netherlands (Fig. 7.1). It is characterized by a marked salinity gradient and a virtually completely mixed water column. The resi- dence time of the water is about 60 days or 120 tidal cycles in the mesohaline zone (Soetaert \& Herman 1995b). Salinity zones in the estuary remain relatively stable and are maintained in more or less the same position throughout a tidal cycle (Heip 1989b). The major part of the estuary is characterized by two parallel subtidal channels separated by large sandflats and bordered by tidal mudflats and marshes (Van Maldegem et al. 1993). The abiotic environment is discussed in Heip (1989b) and Van Eck et al. (1991).

Demersal fishes were sampled with 3 and 2$\mathrm{m}$ beam trawls equipped with fine-meshed nets $(5 \times 5$ $\mathrm{mm}$ ) and a tickler chain. From January 1990 to December 1991, monthly samples were taken subtidally (-10 m depth) in 14 stations between Vlissingen and Bath. Concurrently, the hyperbenthos was sampled with a sledge equipped with nets with a 1-mm mesh size. Details of the sampling methodology and results for the hyperbenthic compartment are given in Mees et al. (1993a), Mees et al. (1993b) and Mees et al. (1994). From March to October 1992, the intertidal sandflat of Valkenisse was sampled monthly at depths of $-1 \mathrm{~m}$ and $-3 \mathrm{~m}$. Trawling was always carried out with the tide at an average speed of 4.5 knots relative to the bottom and over a distance of $1000 \mathrm{~m}$. All fish and mysids were identified to species level, measured and counted. Fish were anaesthetised with benzocaine to prevent-regurgitation of the stomach contents and preserved in a $7 \%$ formaldehydeseawater solution. Densities were standardized as numbers of individuals per $1000 \mathrm{~m}^{2}$. More details on the spatial and temporal community structure of the epibenthos are given in Chapter 2-Add.1 and Chapter 2 ; data on the fauna of the intertidal sandflat are presented in Hostens et al. (1996).

Based on the local and seasonal patterns in the species composition and on the length-frequency distributions of the dominant species, 1486 individuals belonging to 25 fish species (mostly O- or 1group individuals) were selected for stomach content 
analysis. All prey items were identified to the highest taxonomic separation possible. The diet composition is summarized as the numerical percentage of the main prey taxa per fish species and as frequency of occurrence for the mysid species. A more detailed description of the diet composition per size class is given for those fish species where mysids were found to be a major component in the diet. The minimal number of mysids consumed, was estimated by multiplying the average number of mysids per stomach by the number of fish present per unit area. This was done for each fish species and for each month separately. The consumption of mysids by the entire demersal fish community of the brackish zone of the Westerschelde estuary was then estimated as the sum of the consumption estimates for all fish species, expressed as number removed from the standing stocks of three mysid species (as measured at the moment of sampling) per $1000 \mathrm{~m}^{2}$ per day.

\subsection{Results}

\subsubsection{Demersal fish community}

From the 45 epibenthic species caught, only a few fish and crustacean species were abundant or common in the Westerschelde. For several species, the mesohaline zone (stations 9-14) was characterized by higher densities than the polyhaline zone (stations 1-
8) (Fig. 7.2). This was especially the case for the one shrimp species: brown shrimp Crangon crangon (L.); for three goby species: sand goby Pomatoschistus minutus (L.), Lozano's goby P. lozanoi (de Buen) and common goby $P$. microps (Krøyer); and for the flatfish species plaice Pleuronectes platessa (L.), floun$\operatorname{der}$ P. flesus (L.), sole Solea solea (L.) and dab $\mathrm{Li}$ manda limanda (L.). Crabs, both shore crab Carcinus maenas (L.) and swimming crab Liocarcinus holsatus (Fabricius) were more important in the polyhaline zone (stations 1-8). Other important fish groups in the mesohaline zone were gadoids, mainly bib Trisopterus luscus (L.) and whiting Merlangius merlangus (L.), and clupeoids, mainly sprat Sprattus sprattus (L.) and herring Clupea harengus (L.).

\subsubsection{Stomach analyses}

Of the 1486 stomachs analysed, 491 stomachs were empty, mainly from plaice, dab, flounder, sprat and sandeel Ammodytes tobianus (L.) (all sampled subtidally) and from intertidally sampled sole (Table 7.1). An average of two different prey species were found per stomach, though some individuals had a more diverse diet ( $>5$ prey species consumed). An average of 14 prey items per stomach was recorded but, if calanoids are excluded, this value is reduced to 6. Some fish species had very high numbers of prey items per stomach (e.g up to 200 in some individuals of sprat).

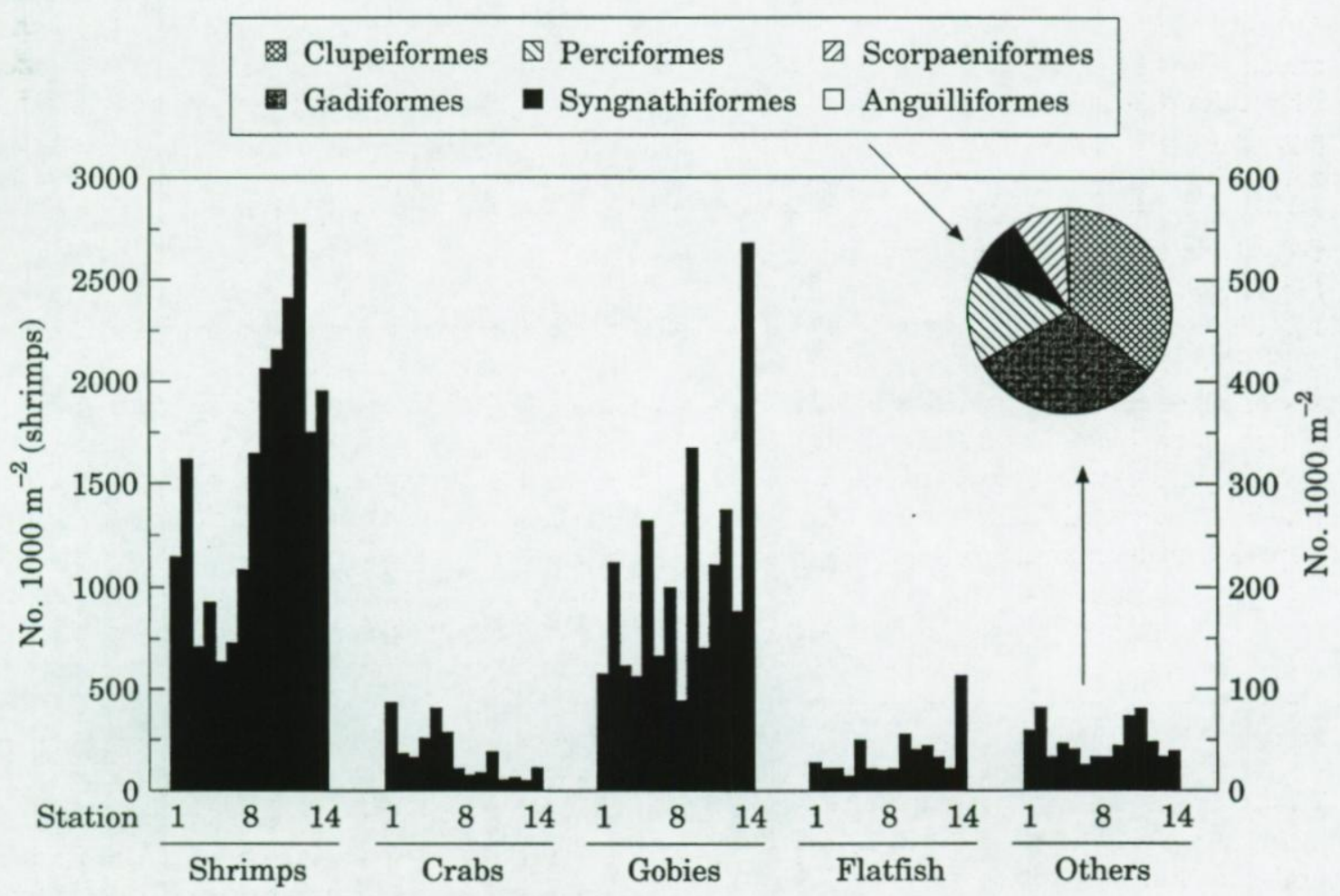

Fig. 7.2 Average density along the salinity gradient per taxonomic group (period 1990-1991, for station numbers see Fig. 7.1, left axis only for shrimp), and the relative numerical composition of the group of other fishes (pie chart) 
Table 7.1 Numbers of stomachs analysed of the 25 fish species, with minimal and maximal $\mathrm{L}_{\mathrm{s}}$, average numbers of prey species and prey items per stomach, relative numerical diet composition for the important prey groups, and frequency of occurrence of the five mysid species; all individuals caught subtidally, unless indicated otherwise

\begin{tabular}{|c|c|c|c|c|c|c|c|c|c|c|c|c|c|c|c|c|c|c|c|c|c|}
\hline \multirow{2}{*}{ Fish Species } & \multicolumn{2}{|c|}{$L_{\mathrm{S}}(\mathrm{mm})$} & \multicolumn{2}{|c|}{ Stomachs } & \multicolumn{3}{|c|}{$\begin{array}{c}\text { Average prey } \\
\text { per stomach }\end{array}$} & \multicolumn{9}{|c|}{ Relative numerical diet composition $\dagger$} & \multicolumn{5}{|c|}{ Frequency of occurrenceł } \\
\hline & Min & $\operatorname{Max}$ & Total & Empty & No. spp. & No. items & No. items* & N.-Mala. & Mysid. & Amphi. & Carid. & O.Crus. & Teleo. & Mollu. & Polyc. & Others & Neo int & Mes sla & Gas spi & Sch spi & Sch ker \\
\hline Clupea harengus & 58 & 109 & 30 & 9 & 2 & 45 & 7 & 84 & 14 & 0.3 & 0.3 & - & 0.1 & - & 1 & - & 62 & - & - & - & - \\
\hline Sprattus sprattus & 58 & 133 & 68 & 48 & 2 & 201 & 1 & 100 & 0.1 & - & - & 0.1 & - & - & - & - & 10 & - & 5 & - & - \\
\hline Gadus morhua & 48 & 483 & 4 & - & 2 & 5 & 5 & - & 10 & - & 38 & 29 & 14 & - & 5 & - & - & - & 25 & - & - \\
\hline Merlangius merlangus & 45 & 237 & 38 & 1 & 2 & 21 & 11 & 47 & 41 & 1 & 7 & 0.3 & 3 & - & 0.1 & 0.1 & 19 & 3 & 41 & 8 & 3 \\
\hline Trisopterus luscus & 30 & 225 & 132 & 6 & 3 & 17 & 17 & 2 & 78 & 4 & 11 & 1 & 1 & - & 0.4 & - & 57 & 1 & 24 & 1 & 1 \\
\hline Ciliata mustela & 63 & 203 & 31 & 2 & 2 & 8 & 8 & - & 8 & 24 & 51 & 3 & 5 & - & 2 & - & 14 & - & 3 & - & 3 \\
\hline Dicentrarchus labrax & 38 & 193 & 9 & - & 3 & 21 & 11 & 49 & 21 & 11 & 8 & - & - & - & 7 & - & 22 & - & 11 & - & 11 \\
\hline Liparis liparis & 26 & 71 & 30 & 1 & 2 & 9 & 7 & 17 & 14 & 49 & 19 & - & 0.4 & - & 0.4 & 0.4 & 31 & - & 3 & 3 & - \\
\hline Ammodytes tobianus & 64 & 176 & 51 & 44 & 3 & 29 & 3 & 91 & - & - & - & 1 & - & - & 3 & 2 & - & - & - & - & - \\
\hline Hyperoplus lanceolatus & 181 & 186 & 2 & 2 & - & - & - & & & & & & & & & & & & & & \\
\hline Callionymus lyra & 94 & 103 & 3 & 1 & 2 & 2 & 2 & - & - & 25 & 50 & 25 & - & - & - & - & - & - & - & - & - \\
\hline Pomatoschistus microps & 23 & 54 & 52 & 3 & 2 & 11 & 3 & 75 & 3 & 4 & 0.2 & 0.2 & - & - & 1 & 17 & 16 & 2 & - & - & - \\
\hline Pomatoschistus mimutus & 19 & 67 & 284 & 25 & 2 & 5 & 3 & 43 & 34 & 14 & 1 & 1 & 0.1 & - & 1 & 6 & 59 & 34 & 2 & - & 0.4 \\
\hline Pomatoschistus lozanoi & 23 & 54 & 236 & 21 & 2 & 3 & 2 & 28 & 55 & 15 & 1 & 0.4 & 0.1 & - & 0.3 & - & 57 & 43 & 3 & 0.5 & 0.5 \\
\hline Pleuronectes platessa (intertidal) & 13 & 119 & 34 & 1 & 3 & 47 & 26 & 45 & 2 & 9 & 2 & $0-1$ & - & 7 & 20 & 15 & 21 & - & - & - & 3 \\
\hline Pleuronectes platessa & 49 & 248 & 134 & 106 & 1 & 1 & 1 & - & 70 & - & - & - & - & 18 & 9 & - & 4 & - & 7 & - & - \\
\hline Limanda limanda & 53 & 273 & 123 & 102 & 1 & 2 & 2 & - & - & - & 6 & 3 & - & 86 & - & - & - & - & - & - & - \\
\hline Pleuronectes flesus (intertidal) & 170 & 360 & 30 & 4 & 1 & 12 & 12 & - & 32 & 58 & 6 & 0.3 & 2 & 1 & - & - & 35 & - & - & - & - \\
\hline Pleuronectes flesus & 79 & 362 & 102 & 86 & 1 & 6 & 6 & - & 1 & 7 & 12 & - & 3 & 73 & 2 & - & - & - & 6 & - & - \\
\hline Solea solea (intertidal) & 64 & 286 & 49 & 18 & 2 & 8 & 7 & 3 & $i$ & 68 & 18 & 2 & - & - & 7 & - & 3 & - & 3 & - & - \\
\hline Anguilla anguilla & 235 & 650 & 21 & 4 & 1 & 5 & 5 & - & - & 31 & 14 & 11 & 43 & 1 & - & - & - & - & - & - & - \\
\hline Belone belone & 129 & 129 & 1 & - & 2 & 9 & 8 & 11 & 89 & - & - & - & - & - & - & - & - & 100 & - & - & - \\
\hline Gasterosteus aculeatus & 50 & 67 & 3 & 3 & - & - & - & & & & & & & & & & & & & & \\
\hline Trigla lucerna & 126 & 249 & 8 & 2 & 2 & 14 & 14 & - & 54 & - & 45 & 1 & - & - & - & - & 33 & - & - & - & - \\
\hline Myoxocephalus scorpius & 114 & 214 & 3 & - & 2 & 2 & 2 & - & - & - & 57 & 14 & 29 & - & - & - & - & - & - & - & - \\
\hline Enophrys bubalis & 81 & 153 & 2 & - & 2 & 2 & 2 & - & - & - & 33 & - & 33 & - & - & - & - & - & - & - & - \\
\hline Agonus cataphractus & 66 & 138 & 6 & 2 & 2 & 4 & 4 & 13 & 13 & 50 & 19 & - & - & - & - & - & 25 & - & $\overline{25}$ & - & - \\
\hline 25 & & & 1486 & 491 & 2 & 14 & 6 & 54 & 24 & 8 & 5 & 1 & 1 & 2 & 3 & 3 & 42 & 18 & 7 & 1 & 1 \\
\hline
\end{tabular}

-Average number of items without Non-Malacostraca

† Non-Malacostraca, Mysidacea, Amphipoda, Caridea, Other Crustacea (Brachyura, Isopoda), Teleostei, Mollusca, Polychaeta, Others (Detritus, Ctenophora).

¥Neomysis integer, Mesopodopsis slabberi, Gastrosaccus spinifer, Schistomysis spiritus, Schistomysis kervillei. 
Besides some unidentifiable material and faecal pellets, 44 different prey species were recorded (Table 7.2). Only 13 species were very abundant: palps of polychaetes (probably from the capitellid Heteromastus filiformis (Claparède)), siphons of bivalves (probably exclusively from Macoma baltica (L.)), the calanoid copepods Eurytemora affinis (Poppe) and Temora longicornis (Müller), the gammaridean amphipods Corophium volutator (Pallas), Gammarus salinus (Spooner) and Bathyporeia species, the mysids Neomysis integer (Leach), Gastrosaccus spinifer (Goës) and Mesopodopsis slabberi (van Beneden), different developmental stages of Crangon crangon, postlarval gobies (different Pomatoschistus species) and postlarval clupeoids (probably a mixture of Clupea harengus and Sprattus sprattus).
Mysids were found in more than half of the stomachs and they were taken by 19 fish species (Table 7.1). They dominated (>50\%) the diet of subtidally sampled bib, lozano's goby, plaice, tub gurnard Trigla lucerna (L.) and garfish Belone belone (L.). They were subdominant (between 10 and $50 \%$ ) in the diets of herring, whiting, seabass Dicentrarchus labrax (L.), sea snail Liparis liparis (L.), sand goby, flounder (intertidally caught), and hooknose Agonus cataphractus (L.). No mysids were recorded from the stomachs of sandeel, dragonet $\mathrm{Cal}$ lionymus lyra (L.), dab, eel Anguilla anguilla (L.), bull rout Myoxocephalus scorpius (L.) and sea scorpion Enophrys bubalis (Euphrasen). The calanoids $E$. affinis and $T$. longicornis were numerically important prey for several species, especially for the two clu-

Table 7.2 Overview of all 44 prey species identified in the stomach content analyses of the 25 fish species, with the total number of prey items found in all stomachs per prey group and per prey species

\begin{tabular}{|c|c|c|c|c|}
\hline Prey Group & Total & Prey species & No. & Remarks \\
\hline \multirow[t]{8}{*}{ Polychaeta } & 387 & Polychaeta spp. & 12 & \\
\hline & & Heteromastus filiformes & 268 & $\begin{array}{l}\text { Mostly palps, probably } \\
\text { exclusively from this species }\end{array}$ \\
\hline & & Nereis virens & 41 & $\begin{array}{l}\text { Often recorded as Nereidae } \\
\text { spp. }\end{array}$ \\
\hline & & Eteone longa & 31 & \\
\hline & & Lanice conchilega & 5 & Also Aulophora larvae \\
\hline & & Pygospio elegans & 4 & \\
\hline & & Spiophanes spp. & 4 & \\
\hline & & Anaitides spp. & 2 & \\
\hline \multirow[t]{4}{*}{ Mollusca } & 211 & Macoma baltica & 119 & $\begin{array}{l}\text { Mostly siphons, probably } \\
\text { this species }\end{array}$ \\
\hline & & Ensis spp. & 88 & \\
\hline & & Spisula spp. & 3 & Spat \\
\hline & & Littorina spp. & 1 & Single record \\
\hline \multirow{10}{*}{$\begin{array}{l}\text { Non- } \\
\text { Malacostraca }\end{array}$} & 7481 & Daphnia magna & 556 & Recorded in only 1 stomach \\
\hline & & Daphnia pulex & 12 & Recorded in only 1 stomach \\
\hline & & Copepoda spp. & 1625 & \\
\hline & & Eurytemora affinis & 3866 & \\
\hline & & Temora longicornis & 1102 & \\
\hline & & Acartia spp. & 154 & \\
\hline & & Centropagus hamatus & 4 & \\
\hline & & Paracalanus parvus & 1 & Single record \\
\hline & & Euterpina acutifrons & 140 & \\
\hline & & Cirripedia spp. & 20 & Only cypris Larvae \\
\hline \multirow[t]{8}{*}{ Amhipoda } & 1145 & Corophium volutator & 452 & $\begin{array}{l}\text { Often recorded as } \\
\text { Corophium spp. }\end{array}$ \\
\hline & & Gammarus salinus & 321 & \\
\hline & & Bathyporeia spp. & 330 & \\
\hline & & Corophium arenarium & 34 & \\
\hline & & Pontocrates altamarimus & 3 & \\
\hline & & Jassa falcata & 2 & \\
\hline & & Pleusymtes glaber & 2 & \\
\hline & & Parajassa pelagica & 1 & Single record \\
\hline \multirow[t]{2}{*}{ Isopoda } & 14 & Lekanosphaera rugicauda & 11 & \\
\hline & & Idotea linearis & 3 & \\
\hline \multirow[t]{5}{*}{ Mysidacea } & 3350 & Neomysis integer & 1875 & Marsupial larvae separated \\
\hline & & Gastrosaccus spinifer & 1115 & Idem \\
\hline & & Mesopodopsis slabberi & 324 & \\
\hline & & Schistomysis kervillei & 27 & Idem \\
\hline & & Schistomysis spiritus & 9 & \\
\hline Caridea & 659 & Crangon crangon & 659 & $\begin{array}{l}\text { Zoeae, postlarvae and } \\
\text { juveniles }\end{array}$ \\
\hline \multirow[t]{4}{*}{ Brachyura } & 42 & Carcinus maenas & 24 & \\
\hline & & Liocarcinus holsatus & 11 & \\
\hline & & Portummus latipes & 5 & \\
\hline & & Liocarcinus arcuatus & 2 & \\
\hline \multirow[t]{3}{*}{ Teleostei } & 111 & Pisces species & 7 & \\
\hline & & Pomatoschistus spp. & 72 & \\
\hline & & Clupeidae spp. & 31 & Single record \\
\hline \multirow[t]{4}{*}{ Others } & & Ctenophora spp. & 1 & Single record \\
\hline & & $\begin{array}{l}\text { Faecal pellets } \\
\text { Unidentifiable material }\end{array}$ & & \\
\hline & 13400 & 44 & & \\
\hline & & & & \\
\hline
\end{tabular}


Table 7.3 Number of stomachs analysed and relative numerical diet composition per length class for two goby species

\begin{tabular}{|c|c|c|c|c|c|c|c|c|c|c|c|c|c|c|c|c|}
\hline Fish $L_{\mathrm{S}}(\mathrm{mm})$ & $19-21$ & $22-24$ & $25-27$ & $28-30$ & $31-33$ & $34-36$ & $37-39$ & $40-42$ & $43-45$ & $46-48$ & $49-51$ & $52-54$ & $55-57$ & $58-60$ & $61-63$ & $67-69$ \\
\hline \multicolumn{17}{|l|}{ Pomatoschistus minutus } \\
\hline No. stomachs & 2 & 2 & 4 & 7 & 7 & 17 & 45 & 37 & 58 & 60 & 23 & 8 & 3 & 7 & 2 & 1 \\
\hline Calanoidea & 100 & 82 & 97 & 50 & 35 & 17 & 4 & 22 & 28 & 21 & 71 & 58 & 37 & 59 & 0 & 100 \\
\hline Mysidacea & 0 & 18 & 1 & 27 & 6 & 46 & 68 & 50 & 46 & 44 & 22 & 22 & 0 & 21 & 60 & 0 \\
\hline Amphipoda & 0 & 0 & $i$ & 0 & 9 & 32 & 25 & 25 & 14 & 24 & 7 & 5 & 11 & 15 & 20 & 0 \\
\hline Others & 0 & 0 & $i$ & 23 & 49 & 5 & 3 & 3 & 12 & 11 & 0 & 15 & 53 & 5 & 20 & 0 \\
\hline \multirow{2}{*}{\multicolumn{2}{|c|}{$\begin{array}{l}\text { Pomatoschistus lozanoi } \\
\text { No. stomachs }\end{array}$}} & & & & & & & & & & & & & & & \\
\hline & & 1 & 1 & 15 & 29 & 43 & 53 & 47 & 31 & 9 & 4 & 3 & & & & \\
\hline Calanoidea & & 0 & 50 & 13 & 10 & 27 & 21 & 3 & 51 & 41 & 29 & 67 & & & & \\
\hline Mysidacea & & 100 & 50 & 76 & 71 & 61 & 56 & 70 & 36 & 46 & 57 & 33 & & & & \\
\hline Amphipoda & & 0 & 0 & 8 & 17 & 12 & 22 & 24 & 11 & 14 & 7 & 0 & & & & \\
\hline Others & & 0 & 0 & 3 & 2 & 0 & 1 & 3 & 2 & 0 & 7 & 0 & & & & \\
\hline
\end{tabular}

peoids herring and sprat, for whiting and for most perciforms. The amphipod C. volutator was important in sole and in intertidally caught flounder, while G. salinus and Bathyporeia species were important in the diets of sea-snail and gobies, respectively.

The shrimp $C$. crangon was most important in the diets of the gadoids, especially five-bearded rockling Ciliata mustela (L.) and cod Gadus morhua (L.), in dragonet and in the scorpaeniform fish species, e.g tub gurnard and hooknose. Bivalve siphons were mainly taken by older flatfishes from the subtidal area and by juvenile plaice intertidally, while fragments of teleost fish were found mainly in the
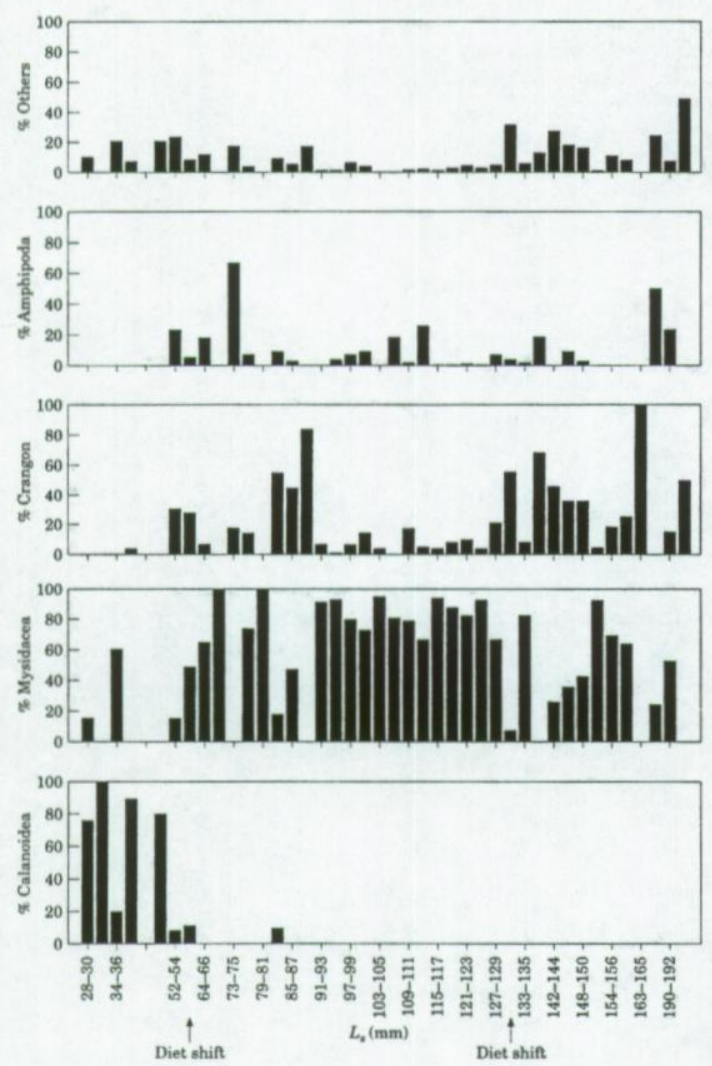

Fig. 7.3 Relative numerical diet composition for Trisopterus luscus per length class stomachs of older eel, bull rout, cod, rockling and whiting. Palps of capitellid polychaetes were recorded from intertidal plaice, and segmented fragments of several polychaete species were taken by sole, plaice, seabass and sandeel. Unidentifiable prey fragments and faecal pellets were most abundant in common goby and intertidal plaice.

\subsubsection{Niche shift}

The stomach contents of 284 Pomatoschistus minutus between 19 and $67 \mathrm{~mm}, 236$ P. lozanoi between 23 and $54 \mathrm{~mm}$, and 126 Trisopterus luscus between 30 and $210 \mathrm{~mm} \mathrm{LS}$ were analysed. For both gobies, calanoids were numerically important prey items (Table 7.3). They were the dominant prey item for several length classes of sand goby $(<30$ and $>50$ $\mathrm{mm}$ ). Between 30 and $50 \mathrm{~mm}$ the species mainly preyed upon mysids, while they supplemented their diet with amphipods. Lozano's goby seems to be a mysid feeder throughout its life, though amphipods and calanoids became more important in the diet of medium-sized and larger individuals, respectively (Table 7.3). Bib showed a clear diet shift from calanoids to mysids at a length of $50 \mathrm{~mm}$ (Fig. 7.3). A second shift from mysids to shrimp was observed at a length of $130 \mathrm{~mm}$. These larger size classes also fed to a large extent on mysids, but the strictly hyperbenthic Neomysis integer has more or less been replaced by the larger, epibenthic Gastrosaccus spinifer.

\subsubsection{Consumption of mysids}

Neomysis integer was preyed upon by 15 fish species. It occurred in $>50 \%$ of the stomachs of bib, sandgoby, lozano's goby and herring (Table 7.1). Mesopodopsis slabberi occurred in 30 and $40 \%$ of the stomachs of sandgoby and lozano's goby, respectively. Gastrosaccus spinifer was mainly taken by bib, whiting and cod. Schistomysis spiritus and $S$. kervillei were less important, although they were 

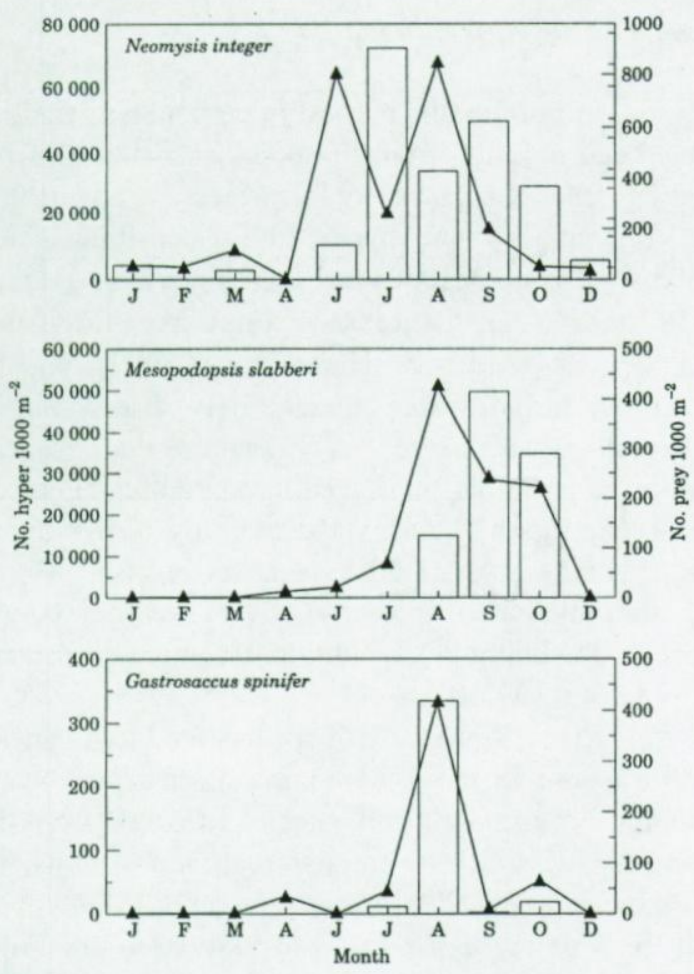

Fig. 7.4 Monthly density pattern of three mysid species as caught with a hyperbenthic sledge (left axis, line) (Mees et al. 1993a, Mees et al. 1994), in comparison with the recalculated number of consumed mysids by all 25 fish species caught with a 3- $\mathrm{m}$ beam trawl (right axis, bars), in the mesohaline part of the Westerschelde

recorded from stomachs of seabass and whiting, for example.

Only small fractions of the standing stock of the $N$. integer and $M$. slabberi populations were consumed per day by all demersal fish species together. For example, maximally 800 out of $80000 \mathrm{~N}$. integer and 400 out of $50000 \mathrm{M}$. slabberi per $1000 \mathrm{~m}^{2}$ were taken by fish in July and September, respectively (Fig. 7.4). The seasonal consumption pattern followed the density pattern of the prey population for both $N$. integer and $M$. slabberi. A single peak of 400 individuals per $1000 \mathrm{~m}^{2}$ was observed for Gastrosaccus spinifer in summer, while about the same number of individuals was found to be consumed per day by the fish community.

\subsection{Discussion}

\subsubsection{General}

The structural pattern found in the mobile epibenthic fauna of the Westerschelde estuary in the period $1990-1991$ is comparable with the results for 1988 and 1989 (Chapter 2-Add.2, Chapter 2). These studies described a clear separation between a polyhaline (stations 1 to 8 ) and a mesohaline (stations 9 to 14) zone, the latter being characterized by higher densi- ties of both invertebrates and fishes. The mobile epibenthic fauna is dominated by invertebrate species in both zones: the shrimp Crangon crangon occurred in much higher densities than all fish species together. Also for other compartments like the hyperbenthos and the zooplankton, the mesohaline zone is characterized by much higher densities and biomasses (e.g Mees et al. 1993b, Soetaert \& Van Rijswijk 1993, Chapter 8-Add.).

Most of the 44 fish species were recorded in low average densities ( 34 species with $<1$ individual per $1000 \mathrm{~m}^{2}$ ). The few abundant species were caught mainly as juveniles, especially in the mesohaline zone. The Westerschelde is, therefore, considered to be a nursery area for 8 fish species: Pomatoschistus minutus, P. lozanoi, P. microps, Limanda limanda, Pleuronectes platessa, Trisopterus luscus, Sprattus sprattus and Solea solea. For this study, the diet of these species was investigated. Further, stomach contents were analysed for all other fish species that were found to be locally and/or seasonally abundant, i.e. Clupea harengus, Liparis liparis, Pleuronectes flesus, Ammodytes tobianus, Ciliata mustela, Merlangius merlangus, Anguilla anguilla, Dicentrarchus labrax, and for some rarer species (Trigla lucerna, Agonus cataphractus, Gadus morhua, Callionymus lyra, Myoxocephalus scorpius, Enophrys bubalis, Hyperoplus lanceolatus and Belone belone).

\subsubsection{Habitat use}

Stomach contents were analysed from fishes taken from both subtidal and intertidal areas. Although this is not presented in the results section, the species may be divided clearly into three groups according to their foraging strategy. A first group utilizes only the subtidal reaches (e.g gadoids and clupeoids) where they prey mainly upon mobile hyper- and epibenthic species. A second group (e.g flatfishes) forages mainly intertidally, taking sessile or buried endobenthic prey. A third group of species (e.g gobies) did not show a clear preference, feeding in both subtidal and intertidal areas.

Similar feeding patterns have been observed in other areas. In the lower Medway estuary (UK), for example, the gadoids Trisopterus luscus and Merlangius merlangus predominantly fed on fast-moving brown shrimp, mysids and small fish, while pleuronectids preferred tubificid and polychaete worms (van den Broek 1978). In the western Irish Sea, 13 fish species were divided into a group that preyed predominantly on mobile prey organisms such as decapods, mysids, copepods and fish, and a second group that exploited mainly in/epifaunal organisms such as polychaetes, bivalves and echinoderms (McDermott \& Fives 1995). In the present study area, only $20 \%$ of 134 juvenile plaice sampled subtidally had full stomachs and had consumed mainly mysids (Gastrosaccus spinifer and Neomysis inte- 
ger), bivalves (Ensis spp.) and polychaetes (Nephtys spp.). These were almost certainly taken in intertidal areas. Plaice that were sampled intertidally invariably had full stomachs. They had mainly cropped bivalve siphons, most probably from Macoma baltica which is the most abundant bivalve species on the sandflat of Valkenisse (Ysebaert et al. 1993). Also, $>80 \%$ of 102 flounder stomachs from the subtidal areas were empty. On the intertidal flat, most stomachs were full and their diet consisted mainly of Corophium species and, to a lesser extent, mysids. Sole has also been reported to perform tidal migrations. The high percentage of empty stomachs, even on the intertidal flat, probably reflects a nocturnal feeding behaviour (Boerema 1964). The stomachs of juvenile dab in the subtidal areas were nearly always empty. This suggests that dab uses mainly the estuary as a wintering area where they survive on their fat-reserves.

\subsubsection{Diet composition}

As in most estuarine systems, the immigration or appearance of early life-history stages of most fish species in the mesohaline zone of the Westerschelde coincides with peak densities of the dominant copepod species Eurytemora affinis (Soetaert \& Van Rijswijk 1993). Several fish species then show a diet shift: as the fish grow, mysids replace copepods progressively in the diet. This was clearly the case for 30-mm Pomatoschistus minutus, which can be related to a transition from a planktonic to a demersal life style (R.V. Arellano et al. unpublished data). In the Po River Delta (Italy), sea bass also shifted preference from copepods towards mysids at a length of $30 \mathrm{~mm}$ (Ferrari \& Chieregato 1981). In the Westerschelde, mysids were an important prey item for both sandgoby and lozano's goby. In Belgian coastal waters, Pomatoschistus minutus preyed mainly upon parts of sessile organisms, such as polychaete radioles, bivalve siphons and amphipods (Hamerlynck \& Cattrijsse 1994) while the sympatric P. lozano $i$ preyed mainly upon mysids, small shrimps, amphipods and early postlarval fish (Hamerlynck et al. 1990). It can be argued that in coastal areas, where mysids are less abundant than in estuaries (Mees et al. 1993a), feeding niches are spatially segregated through interspecific competition, with $P$. minutus feeding closer to the bottom than $P$. lozanoi. In the brackish water zone of estuaries, where food is unlikely to be a limiting factor since hyperbenthic densities are high throughout the year, both species prefer to feed on mysids. The diets of the gadoids Trisopterus luscus and Merlangius merlangus shifted from calanoids to mysids and amphipods, and then to shrimps and small fishes, as has also been observed in other studies (e.g Chapter 7-Add.). Still, mysids are clearly more important in the diet of estuarine bib populations than for bib in coastal areas.

\subsubsection{The mysid-feeding guild}

In Europe, the highest hyperbenthic densities have been reported from the brackish reaches of estuaries (Mees et al. 1993b, Mees et al. 1995). Throughout the year, hyperbenthic densities in the polyhaline zone of the Westerschelde are on average 5-10 times lower than those reported from the mesohaline zone (Mees \& Hamerlynck 1992). In the maximum turbidity zone, the numbers of sessile macrobenthic organisms generally decrease due to burial and/or clogging of their feeding apparatus (Pearson \& Rosenberg 1987). Also, the mobility of hyperbenthic species can be an advantage, for example allowing an immediate response to adverse oxygen conditions in the unpredictable environment of an estuary (Mees et al. 1993b).

Many demersal fish species feed to a considerable extent in the hyperbenthic part of the water column. From the 44 prey species recorded from the stomachs, 35 species were also recorded from hyperbenthos samples taken in the same area (Mees et al. 1993b, Mees et al. 1995). Most of these are holohyperbenthic taxa (e.g mysids and gammaridean amphipods), while others belong to the merohyperbenthos (e.g larval shrimps, crabs and fish) or to the mesozooplankton that happens to be present in the water layers close to the substratum (e.g the calanoid copepods). Also, taxa that are generally described as endobenthic are known to perform regular excursions into the water column (examples are macrobenthic Amphipoda and meiobenthic Harpacticoida: see Mees \& Jones (1997) for a review). These temporary hyperbenthic individuals, although they constitute a small fraction of the total endobenthic population, are obviously more vulnerable to fish predation.

Mysidacea are probably the most typical hyperbenthic taxon (Mauchline 1980, Mees \& Jones 1997). In a review on the occurrence of mysids in the diet of fish, Mauchline (1980) reports 51 and 12 fish species that feed on mysids in the Northeast Atlantic and the Mediterranean, respectively. Since that time, mysid-feeding guilds have been distinguished in several demersal fish assemblages (Mees \& Jones 1997). In the intertidal mudflats of the upper Tagus estuary (Portugal), for example, the group of mysid-eaters included Dicentrarchus labrax, two Pomatoschistus spp. and three Syngnathus spp. (Moreira et al. 1992). Based on the diet of 17 fish species from the Cananeia estuary (Brazil), Ribeiro et al. (1997) distinguished four feeding groups, with one group that mainly fed on suprabenthic mysids and copepods. Burke (1995) suggested that the estuarine gradient in mysid densities might influence the movement of southern flounder Paralichthys lethostigma (Jordan and Gilbert) to their nursery grounds.

In the Westerschelde, the two most abundant mysid species are Neomysis integer and Mesopodopsis slabberi. Both species reached average densities 
of $>10$ individuals per $\mathrm{m}^{2}$ in the mesohaline subtidal zone (Mees et al. 1993a). It is obvious that mainly these two species were preyed upon by the different fish species. $N$. integer is a typical endemic of brackish waters and it is very abundant in both the subtidal channels and intertidal saltmarsh creeks (Mees et al. 1993a). Peak densities of $>100$ individuals per $\mathrm{m}^{2}$ in the subtidal were noted in summer (Mees et al. 1994). M. slabberi is very abundant in fully marine and in brackish waters. In the Westerschelde, it enters the mesohaline zone mainly in the summer period, where it occurs generally somewhat higher in the hyperbenthal layer, as compared to $N$. integer. The occurrence of Gastrosaccus spinifer is correlated with sediment characteristics and seems to be independent of salinity (Mees et al. 1993a). The low densities of $G$. spinifer estimated from the subtidal sledge samples (Fig. 7.4) are probably severe underestimates as the species buries itself in the sand of shallow areas. The second peak of mysids in the diet of Trisopterus luscus $\left(>140 \mathrm{~mm} \mathrm{~L} \mathrm{~L}_{\mathrm{S}}\right)$ consisted mainly of $G$. spinifer. The three other mysid species of the Westerschelde were preyed upon only rarely in the Westerschelde. Praunus flexuosus (Müller) is essentially an intertidal species that is probably too large a prey item for juvenile fishes. Both Schistomysis spiritus (Norman) and S. kervillei (G.O. Sars) are more marine species that do not penetrate far into the estuary (Mees et al. 1993a). While juvenile $T$. luscus fed mainly upon $N$. integer in the Westerschelde, $S$. kervillei was the most important mysid species in its diet in an adjacent coastal area (Chapter 7-Add.).

This study confirms that the hyperbenthos, and mysids in particular, are important in the diet of $\mathrm{O}$-group individuals of several fish species in the mesohaline zone of the Westerschelde estuary. Only a small fraction of the mysid populations, however, seems to be consumed by the demersal fish community (on average $1 \%$ of the standing stock of mysids per day). Of course this has to be seen as a minimal consumption estimate. In this study it is assumed that the stomach content represents a feeding period of 24 hours. Several studies indicated a cyclical food intake by different fish species with bursts of feeding either related with light (more feeding at dawn and dusk or during day or night) or related with the tides (more feeding around high water). Other studies showed the opposite, where fish species feed till they are saturated and start feeding again when the stomach is emptied (see Elliott et al. 2002). Mysids are known to concentrate near the bottom at high current velocities (J. Mees, pers. comm.). As such they may be more vulnerable to predation between high and low water, when the highest current velocities occur (i.e. 4 times a day). Therefore, we suggest that a maximal consumption estimate of $4 \%$ of the standing stock of mysids per day (indicating the fish have been feeding 4 times the amount that was found at a certain sampling moment, per day throughout the year) would be more appropriate.

Still, this is only a rough estimate, as consumption estimates should take into account daily rations and gastric evacuation rates of the different fish species on the one hand and secondary production rather than standing stock values on the other. The present study only intended to give a basic idea of what amount of the mysid population was consumed. Even the $4 \%$ estimate provides an argument against top-down control mechanisms as major driving forces of invertebrate population structures in estuaries. Preliminary results indicate that the highly abundant shrimp Crangon crangon may be the most important predator on mysids (Chapter 8 ).

\footnotetext{
Acknowledgements We would like to thank Wim Röber, Piet de Koeyer, Co van Sprundel and Hans Francke of the R.V. Luctor for their help during sampling. Louise Puturuhu, Christopher Muhando, Mattias Verbeke and Peter Sas did part of the stomach analyses. This study was financed by project $\mathrm{n}^{\circ}$ BOF $98-03$, 12.0503 .98 of the University of Gent and by project $n^{\circ} \mathrm{G} .0104 .99$ of the Flemish Science Foundation.
} 
